\title{
History of books and journals and periodicals in rheumatology
}

\author{
E G L Bywaters*
}

'Rheum' comes from the Greek-a 'watery discharge' $(O E D)$-and rheumatological literature as we scan it today has had two main historical sources for its now ever faster running river of words: $(a)$ the spa waters and hydrology from the Middle Ages onward, beautifully illustrated in mediaeval woodcuts, and $(b)$ the more modern mainstream of general medicine itself, even more widely and more strongly flowing and with a lot of very fertile silt, which today has almost blocked its older tributary, except perhaps in middle Europe. There, those ancient waterways and spas still flourish, discharging their rheum with state support and the modern gloss of physical medicine, benefiting both doctors and also, perhaps, patients. The earlier medical publications were books: only later did journals appear, based originally on the transactions, proceedings, archives, and acta of the newly formed scientific societies, such as the Royal Society, 1665.

Journals and periodicals

Journals and periodicals began to take over from books in the world of science in the late seventeenth and early eighteenth century with the new learning: observations in the medical field, also burgeoning, began to appear in the philosophical transactions of the Royal Society together with observations on mathematics, physics, chemistry, and the developing biological sciences. Not until the eighteenth century did specifically medical journals begin to appear. Lock traces the further rise of the specialist medical journals from the nineteenth century to date. ${ }^{1}$ Rheumatism journals were late to appear. The first such periodical specifically devoted to rheumatism was published in 1929 by Van Breemen in Holland as Acta Rheumatologica. This was the official journal of the Ligue Internationale contre le Rhumatisme. It continued until the outbreak of war in 1939 when Holland was overrun and Van Breemen's files were confiscated or destroyed. Such other acta and the Archives of Medical Hydrology, trickling on since 1922, are listed comprehensively by Stecher. ${ }^{2}$ He noted 39 journals in 1961, many of which had ceased publication then, and more since. Stecher's listing was brought up to 1969 by Morton and Bywaters, ${ }^{3}$ who cited 33 periodicals, including those in Stecher, from all over the world. Some were short lived, but a later 1978 survey showed an overall proliferation, which continues to this day. Thus the Royal Society of Medicine currently takes 26 rheumatological journals and 11 physical medicine or rehabilitation journals, and this figure takes no account of the drug supported and other free journals. Some of these 26 are vehicles for local and national ambitions without scientific, medical, or social significance-a lot of wasted tropical forest. Impact factors, although slow to show up, indicate where libraries can economise on such journals. The magnificent 'citation index', first introduced by Garfield in $1955,{ }^{4}$ indicates the number of subsequent citations of original individual papers and is usually a good guide to their worth. It can be applied to journals as well or to anything else with a claim on history.

The Annals of the Rheumatic Diseases started in 1939, being a continuation of Reports on Chronic Rheumatic Diseases published in four volumes, 1935-1938, by the British Committee for Chronic Rheumatic Diseases. It has since held a leading place among international rheumatological publications, together with the later (1958) Arthritis and Rheumatism from the United States, as detailed by Thorpe ${ }^{5}$ in a study of citations in 53 periodicals devoted to rheumatism. Arthritis and Rheumatism started after a period of American collaboration and participation on the editorial board of the Annals from 1939 to $1958 .^{6}$

By this time rheumatology was reaching full flood, mainly owing to the postwar discoveries. The year 1948 was the 'annus mirabilis', and discoveries included the LE cell, Rose-Waater test, cortisone, ACTH, new uricosuric agents, antituberculous and anti-inflammatory drugs, such as phenylbutazone, and controlled trials, as well as, in the United Kingdom, the advent of the National Health Service. ${ }^{7}$

Other journals were launched on this swelling tide as rheumatological societies proliferated all over the world (fig 1). Not far behind this surge, floating in the wake, came the free medical press, the 'give away', 'throw away' drug advertisement journals - useful nourishment for seagulls. These came flooding through our letter boxes with much other promotional 'literature'. A few of them were useful and entertaining, such as Michael O'Donnell's World Medicine ${ }^{8}$; others were more specifically related to rheumatology, 'save-me-quick' lists with abstracts and contents titles. Most were terrible.

The early years of general medical periodicals before the full tide of specialisation saw a large number of classic rheumatological contributions, and without any complete listing we could cite Albrecht (1748) and Connor (1695) on ankylosing spondylitis, Haygarth (1813) on rheumatic fever, Prout on gout (1817), Stone on salix (1763), Garrod (1848 and 1854) and Wollaston 


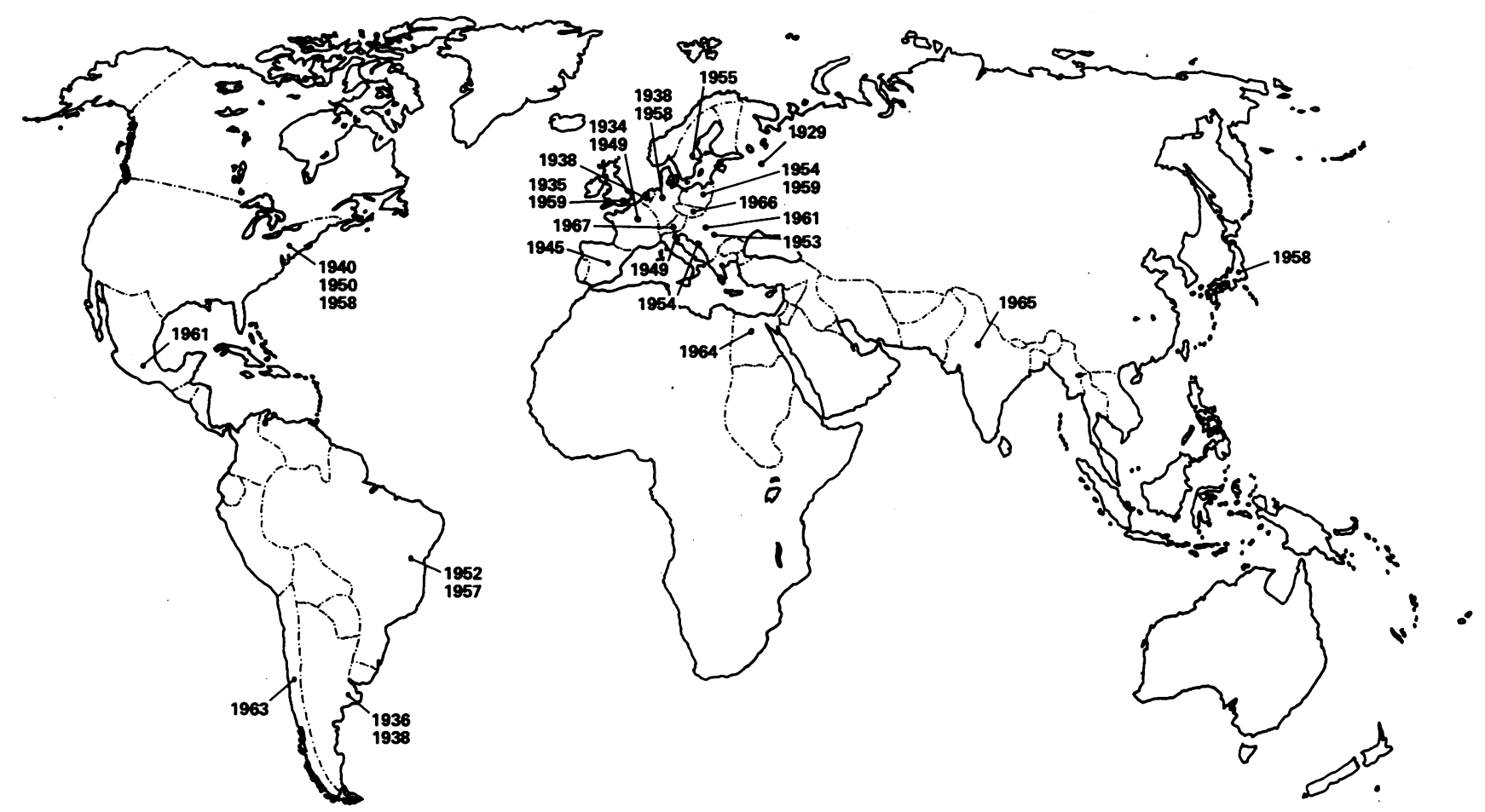

Figure 1 World distribution of rheumatology journals 1929-1967.

(1797) on gout. Today, with xerox facilities, these are less difficult to consult, but we have tried to establish within the Heberden Library a collection of such journal classics reproductions to facilitate historical studies in the field.

\section{Books}

Rheumatological books serve today as collective or, less often, individual views of the rheumatism scene. As they take two years at least to assemble and print, most are out of date by the time of publication in at least many of their details. They serve a useful purpose: to reiterate and reinforce accepted and received knowledge and to spread it. Most valuable are monographs by the expert. But books in the seventeenth to nineteenth centuries were still the repositories of knowledge, however individually biased, and have still today not given way to the newer technologies.

The Heberden Library, ${ }^{*}$ founded in 1936, has one of the best collections of rheumatological books in the world. It contains some 450 books published before 1915, and of these, 134 appeared before 1800 . The oldest books, fifteenth, sixteenth, and seventeenth century, represented therein, number only 19 , from Baillou (1643) with sections on arthritis and 'rheumatism' (which word he is said to have coined), and others published between 1537 and 1697. Of these 19 earliest books, 11 deal with gout, four with arthritis, and three with baths, but it should be remembered that 'de arthritide' often concerned gout as well as rheumatic gout and a host of other things.

Of the 200-250 rheumatic diseases recognised today, ${ }^{9}$ gout was first in the field historically, being described by Hippocrates; it dominated medicine and medical books on rheumatism until the nineteenth century. Was this because gout was much more common then than now? It has been shown that port wines of the nineteenth century contained large quantities of lead, perhaps from lead glazed vessels, ${ }^{10}$ perhaps from added sweetener, accounting for the epidemics of lead poisoning, written up by Wedeen, ${ }^{11}$ such as characterised Rome before its fall, Georgian England, and the epidemics of Queensland, Australia, due to white paint flakes. ${ }^{12}$ Garrod in 1859 noted that 'at least 1 in 4 of the gouty patients who have come under my care at University College Hospital had at some period of their lives been affected with lead poisoning and for the most part followed the occupation of plumbers and painters' ${ }^{13}$

The books of the early nineteenth century are again largely concerned with gout, ${ }^{14}$ but Landré-Beauvais in his thesis of 1800 on ' $\mathrm{La}$ goutte asthenique primitive', had described what Garrod in 1859 named as 'rheumatoid arthritis'. After this, numerous books in the later part of the century dealt with chronic arthritis, rheumatic gout, atrophic arthritis, etc. Indeed, by the end of the century many other types of joint disease had been differentiated, except perhaps osteoarthritis.

\section{Twentieth century books}

Osteoarthritis had been differentiated from other types of chronic arthritis by Goldthwait in Boston (1904) $)^{15}$ and others, but the first comprehensive book devoted to it was published only in 1984 by Moskowitz and coworkers. ${ }^{16}$

The Heberden Library was originally devoted to collecting antiquarian books on gout, rheumatism, and arthritis before 1915 and included few after that date, but it was soon realised that history was happening all around us. We started about 1970 to collect more recent rheumatism books. These are scheduled in part 
II of the catalogue (1915 onwards). They have presented storage problems, in so much as there is an increasing influx of books in this field (demanding selective procedures), but there are many classic books in this period-mainly monographs-summarising the whole of one particular subject. For instance, ankylosing spondylitis, defined and described by Pierre Marie and Léri (and others), ${ }^{17}$ only reached book presentation by Forestier et al in $1951^{18}$ and later by Moll $(1980)^{17}$ and by Calin in 1984. ${ }^{19}$

Chronic arthritis in childhood, now a flourishing industry, although described by Cornil in 1864 and others ${ }^{20}$ later (including G F Still (1896)), reached its book appearance only with Sury in $1952,{ }^{21}$ followed by many more in the '60s, '70s, and '80s.

\section{Textbooks and the development of rheumatism}

Another interesting and hitherto unexplored field is the development of rheumatological presentation and the relative space given to it in successive editions of textbooks of general medicine. A preliminary survey (unpublished) showed that the proportionate page cover for the individual rheumatic diseases in Osler's 1st edition in 1892 to the 16th edition in 1947 had remained relatively unchanged, and the same was true for the textbooks of Cecil, Meakins, Conybeare, and Price.

Although the rheumatology section has expanded considerably since then in the general textbooks, as has its own bookshelf library footage, comparable or often much bigger expansion has occurred with a large number of other specialties and the progression to specialty textbooks was a natural process.

Textbooks of rheumatology in England started with 'Fletcher' in 1949 and 'Copeman' in the same year, and, in the United States, Comroe had already put forward the first comprehensive book on rheumatology in 1940, following Pemberton's two most influential books of 1929 and 1934. Comroe's book went through three editions $(1940,1942,1944)$ and then was carried on by Joe Hollander, also of Philadelphia, and later Dan McCarthy as the American textbook. New ones are now appearing, both textbooks and a large number of more monographic texts, such as textbooks of pediatric rheumatology (Cassidy, Jacobs, and other authoritative productions-for example, by Ansell), monographs on systemic sclerosis by Black, and a famous publication by the late Dubois on systemic lupus erythematosus in 1966. ${ }^{22}$ The pathology of rheumatic diseases became the subject of individual books only in 1949 (Collins), though the classical monographs of Robert Adams or Monro have never been surpassed from the pictorial viewpoint.

\section{Allied subjects}

There is neither space nor time to detail the history of books and journals in orthopaedics (see David le Vay, 1990), ${ }^{23}$ hydrology, physical medicine, rehabilitation, or immunology. Each of these is of considerable interest and would need detailed and specific consideration.

Other types of publications in rheumatology

The year to year progress of rheumatology is also well represented in the Heberden Library (part III) by congress proceedings and by abstracts of symposiums, handbooks, and bulletins, as well as by yearbooks and by the valuable publications of the Arthritis and Rheumatism Council in England intended for public edification. The yearly primers of the Arthritis Foundation (1934 to date) are often considered to contain all you need to know about rheumatology: with 81 chapters, 11 appendices, 113 contributors (not all American); the 9th edition (1988) is a textbook in all but name. It also lists the uniform data bases and glossaries which we shall all use in the future. Other most useful publications from the United States are the Bulletin of Rheumatic Diseases (1950) and the Rheumatism Reviews started in 1935, now published as supplements to Arthritis and Rheumatism.

The Heberden Library has not yet started to collect the ephemera of pharmaceutical handouts, though in years to come these may be as instructive as those eagerly collected items of the Victorian age. We have, however, acquired a number of cassette tape recordings-for example, of the Heberden oration, a musical recording of the rheumatology anthem 'Repertus fons remedii: marche triomphale de la Ligue Internationale contre le Rhumatisme', Frank Hart's 'rheumatological song cycles', etc; these can now be regarded also as rheumatological 'literature'.

Anglo Saxons tend to be increasingly biased in favour of their own language, just as other nations are ${ }^{24}$ We should take note, therefore, as we go into Europe of the very useful bound volumes of L'Actualite Rheumatologique, representing the French view of progress in this field (published regularly 1964 to date), from the Centre Viggo Petersen et l'Hopital Bichat (de Seze, Kahn, etc) as well as the long established Revue du Rhumatisme (from 1934) and Rhumatologie, Aix-les Bains, from 1949. Germany, dominant in medicine before the first world war, is represented by the Zeitschrift für Rheumatologie (formerly Zeitschrift für Rheumaforschung) from 1938.

\section{Illustrations}

Illustrations range from the beautiful woodcuts (fig 2) of the earlier centuries to the equally striking copper and steel engravings of the seventeenth to nineteenth centuries (fig 3), lithography, and photography. Colour lithography began in the nineteenth century and was used by Garrod. Reproductions of $x$ rays and of histological and clinical photographs became universal with the twentieth century. They are often far less clear than earlier types of reproduction but now, sometimes in colour, if sponsors can be found, are much better used together with well planned use of graphics. Graphics are a most welcome addition to our 


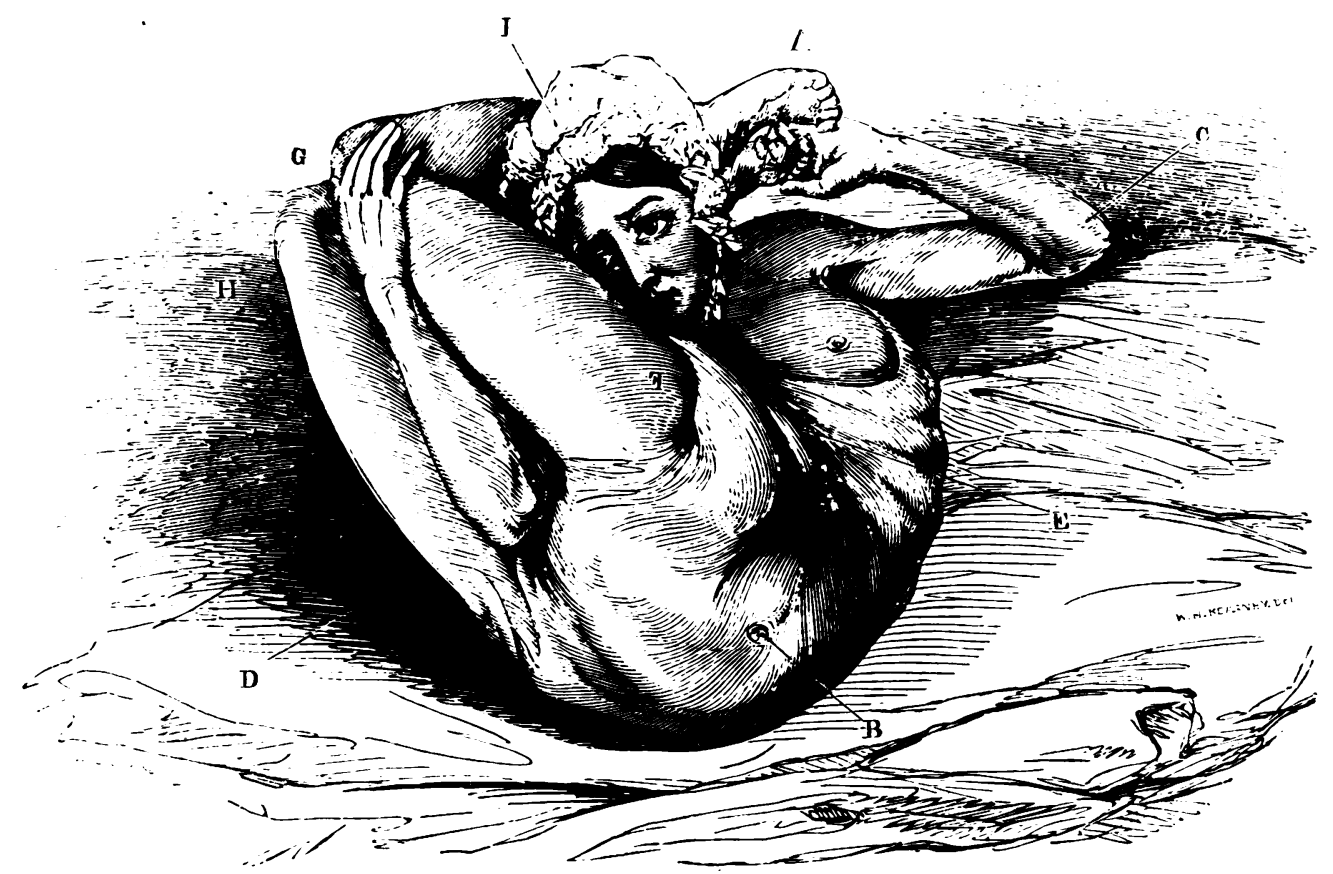

Figure 2 Woodcut showing a woman confined to bed in 1831 after a blow on the cheek three years before. She was examined by 40 doctors. $B y 1840$ she had perfectly recovered. $A=$ feet $; B=$ navel $; C=$ left arm; $D=$ right arm; $E=$ ribs and breast bone raised; $F=$ great trochanter of the right thigh; $G=$ knees; $H=$ right thigh; $I=$ head fixed and inclining to the left, with the chin resting on the breast bone.

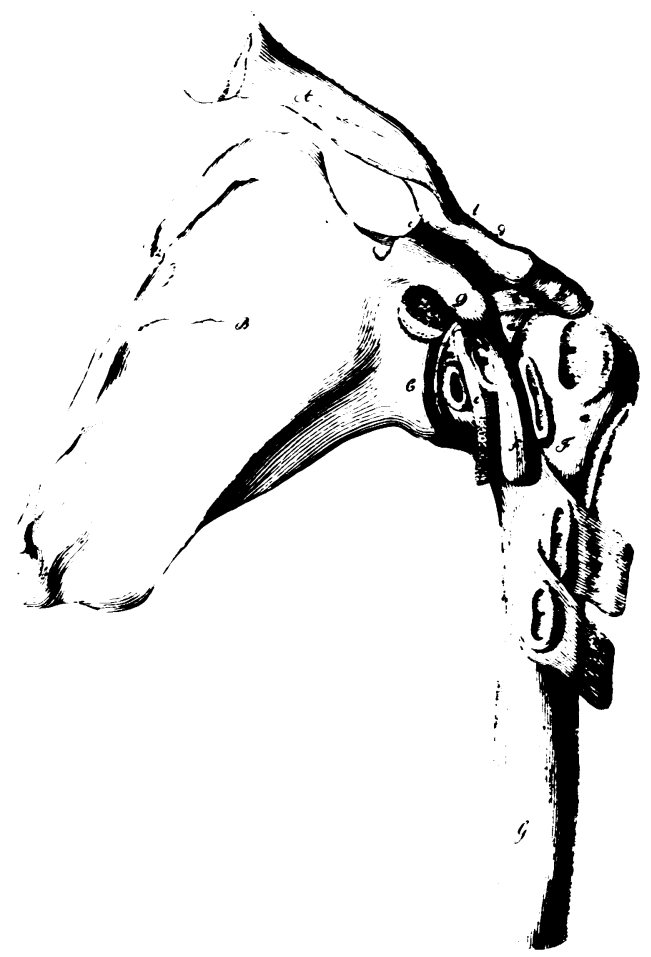

Figure 3 Engraving showing the bursae round the shoulder joint. From: Rosenmuller I C, ed. Monro, Alexander secundus icones et descriptiones bursarum. Leipzig: Breitkopt and Hartek, 1799.

understanding of today's complicated subject matter and particularly valuable in the interpretation of today's advancing concepts of molecular biology and immunology.

Anatomy would have been nothing without the pictures of da Vinci, Gray, and Cunningham: immunology and genetics would fare ill without the arrowed circles of molecular structures and processes, though we could do with a few less speculative Venn diagrams.

\section{Conclusions}

The book has lasted a long time from the incunabula, Gutenberg, 1450, in Mainz and Caxton in England, 1474 onwards. It has been the major factor in the development of Western civilisation. In rheumatology, which developed only recently compared with other specialties, the influence of the book during the eighteenth and nineteenth century was paramount, but more recently, as in all other spheres, its place as the medium of communication has been taken over by journals and more modern technology. With the accelerating progress of medical and all other science the book remains valuable as reference, background, or introductory reading.

Rheumatology as one of the fast advancing medical specialties and led by changes in our population structure is albeit very much dependent on advances in other medical and biological fields. It is today suffering from a surfeit of repetitive information, often indigestible, often commonplace. We need less, not more, new journals. These have been started up recently at an unprecedented rate to cater for splintering specialties, local ambitions, and pharmaceutical occult advertisement.

It has been said that only $1 \%$ of articles in journals are cited more than once in ensuing publications. This is a gross waste of effort, attributable mainly today to the needs of personal promotion, as some publication, however inept, is essential for preferment. The medical demands of our recent Western population restructuring, with its emphasis on geriatrics (a new section of the Royal Society of Medicine formed in 1991) and on the chronic 
diseases which go with it, together with the virtual abolition of rheumatic fever, polio, osteomyelitis, tuberculosis, and other diseases of childhood, should lead to a far reaching revision of our informational balance. That would indeed made history. Perhaps we should work more and write less.

1 Lock S F. Medical journals. In: Walton J, Beeson P B, Bodley Scott $\mathrm{R}$, eds. The Oxford companion to medicine. Oxford: Oxford University Press, 1986: 746-54.

2 Stecher $\mathbf{R}$ M. World list of periodical literature in arthritis and rheumatism. Arthritis Rheum 1961; 4: 378-88.

3 Morton L T, Bywaters $E$ G L. The literature of rheumatism Ann Rheum Dis 1969; 28: 669-73.

4 Garfield E. Citation indexes for Science. Science 1955; 122 108-11.

5 Thorpe $P$. An evaluation of the rheumatology periodica literature used in Britain and the USA. Methods Inf Med 1972; 11: 119-21

6 Smyth C J, Freyberg R H, McEwen C. History of rheumatology in the United States. Georgia: Arthritis Foundation, 1985.

7 Bywaters E G L. Rheumatology. Rheumatism and other connective tissue disorders. In: Walton J, Beeson P B, Bodley Scott R, eds. The Oxford companion to medicine. Oxford: Oxford University Press, 1986: 1266-74.

8 O'Donnell M. World Medicine: a sort of obituary. BMF 1990; 301: 760-8.

9 Huskisson E C, Hart F D. Foint disease: all the arthropathies. 3rd ed. Bristol: Wright, 1978.
10 Ball G V, Sorensen L B. Pathogenesis of hyperuricaemia in saturnine gout. $N$ Engl f Med 1969; 280: $1199-202$

11 Wedeen R P. Poison in the pot. Illinois: South Illinois University, 1984.

12 Emmerson B. Chronic lead arthropathy. Australian Annals of Medicine 1963; 12: 310-24.

13 Garrod A B. Gout and rheumatic gout. London: Bradbury and Evans, 1859

14 Copeman W S C. A short history of the gout and the rheumatic diseases. Berkeley: University of California, 1964.

15 Goldthwait J E. The differential diagnosis and treatment of the so-called rheumatoid diseases. Boston Medical and Surgical fournal 1904; 151: 529-34.

16 Moskowitz R W, Howell D S, Goldberg V M, Mankin H J. Osteoarthritis. Philadelphia: Saunders, 1984

17 Bywaters E G L. Historical introduction. In: Moll J M H, ed. Ankylosing spondylitis. Edinburgh: Churchill Livingstone, 1980: $1-15$.

18 Forestier J, Jacqueline F, Rotes-Querol J. Ankylosing spondylitis. Springfield, USA: Thomas, 1956. (English translation by A U Desjardins.

19 Calin A. Spondyl arthropathies. New York: Grune and Stratton, 1984.

20 Bywaters E G L. The history of paediatric rheumatology. Arthritis Rheum 1977; 20 (suppl): 145-51.

21 Sury B. Rheumatoid arthritis in children. Copenhagen, Munksgaard, 1952

22 Dubois E L. Lupus erythematosus. New York: McGraw-Hill, 1966.

23 le Vay D. The history of orthopaedics. Parthenon, 1990

24 Lennox B. The spread of English. Lancet 1986; i: $683-4$

25 References not in the above list will be found in: The Heberden library catalogue. Sth ed. London: British Society for Rheumatology, 1989. 